\title{
クレゾールスルホン酸類の脱スルホン化速度 ならびに $\boldsymbol{m}$-クレゾールの分離
}

（1974 年 8 月 17 日受理）

\author{
村 本 慶 博 - 朝 倉 英 行*
}

\begin{abstract}
クレゾールスルホン酸類の脱スルホン化速度を測定し，ついでスルホン化-加水分解法を改良して高 純度の $m$-クレゾールを分離することができた。2-メチルフェノール-6-〔1〕拈よび -4-スルホン酸 [2]，3-メチルフェノール-6-[3]扣よび-4-スルホン酸〔4]，4-メチルフェノール-2-スルホン酸 〔5〕をそれぞれ合成し，47\% 臭化水素酸で加水分解するとこの反応が擬一次反応にしたがうことがわ

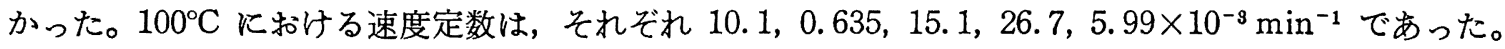
$m$ - およひび p-クレン゙ールを 55〜 65\% 硫酸を用い, $30 \sim 40^{\circ} \mathrm{C}$ で処理すると， $m$-クレン゙ールの反応量は pークレゾールの 3〜5 倍であった。混合クレゾールの改虔分離法として, $90 \%$ 硫酸で $20^{\circ} \mathrm{C}$ に 2 時間 たもち，さらに $100^{\circ} \mathrm{C}$ で 3 時間スルホン化を行ない $(m-ク$ ン゙ールの全部と， $1 / 5$ の $p$-クレゾールが 反応し，廃酸が $65 \%$ になる)，ついで未変化クレン゙ールをベンゼン抽出で除き，スルホン化物に 120 〜 $135^{\circ} \mathrm{C}$ で過熱水蒸気を通じて分解すると, 純度 $97 \sim 99 \%$ の $m$-クレン゙ールが 80 90\% 収率で簡便 に得られた。
\end{abstract}

\section{1 緒 言}

クレジール混合物より，m-クレジールの分離法として，塩頑法， 結晶法および付加物とする方法1), またスルホン化一加水分解法2) など, 古くから多数の提案があるが, いずれも収量, 純度および 簡便さの三点を同時に満足するるのはない。近年第三級ブチル 化一脱ブチル化法采)が工業化されるにいたった。

クレゾールスルホン酸類の脱スルホン化速度の詳細な報告をみ ないので, これを調べ, あわせてクレゾールのいろいろの条件下 に扰けるスルホン化を行ない，ついでスルホン化-加水分解法で， 高純度の $m$ ークレン゙ールを得ることを目的としてこの研究を行な

* 近畿大学工学部工業化学科, 737-01 吳市広町

1）中上 晃, 化学々工業, 2, 253(1949); Chem. Farbrik Ladenburg, D. R. P., 152, 652(1901) ; K. H. Engel, U.S. P., 2, 339, 388(1944)；川崎京市, “有機化合物合成法”, 第 7 集, 有機合成化学協会編 (1955) p. 28 ; R. Rütigers, D. R. P., 141, 421 (1901) ; H. Herisse, E. Desson, D. R.P., 267, 210(1913) ; F. E. Cislak, U. S. P., 2, 456, 581(1948); 宮川一郎, 九大工集集, 11, 120(1936) ; Farben Fabrikan, Bayer A. G., Ger. P., 1, 215, 726(1966).

2) R. Rasschig, D. R. P., 112,545(1899) ; 232, 071(1909) ; A. F. Campbell, Ind. Eng. Chem., 14, 732(1922) ; P.P. Schorygin, J. Appl. Chem. USSR, 9, 1442(1936); H. Brückner, Z. Angew. Chem., 41, 1043(1928) ; F. Hoffmann-LaRocke, D. R. P., 245, 892(1909) ; E. Elger, U. S. P., 1, 025, 616(1912).

3) W. Weinlich, Ind. Eng. Chem., 35, 264(1943); D. B. Luten, U. S.P., 2, 435, $087(1948)$; D. R. Stevens, C. J. Livingstone, U.S.P., 2, 297, 588(1943); 上仲 博 [住友 化学工業(株)], 特許公告, No. 21, 414 (昭和 43.9.13); G. Leston: U. S. P., 3, 470, 259(1970).
った。まず図 1 に示すように, 0 カクレゾールから 2-メチルフェ ノールー6-[1]拈よび-4-スルホン酸 [2], mークレゾールから 3-メチルフェノール-6-[3] 拈よび-4-スルホン酸 [4], p-ク レゾールから 4-メチルフェノール-2-スルホン酸 [5]の純品を それぞれ製した。

mーおよび $p$-クレゾールのスルホン化においては, 低温で希硫 酸と処理することによる反応比は, 約 $5: 1$ であり, またスルホ ン酸類の臭化水素酸による脱スルホン化速度定数比は，〔4]: [5] $\doteqdot 5: 1$ であった。これらのことを利用し小規模で行ならの に特別の設備を必要としないで実験できるスルホン化-加水分解 法についてスルホン化温度, 硫酸量および分解温度なと種々検討 を加え, 高純度の $m$-クレゾールを高収量で得たので報告する。

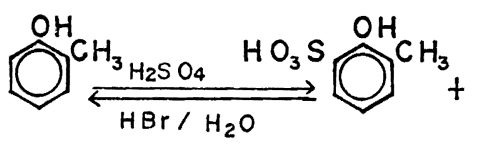

〔1〕

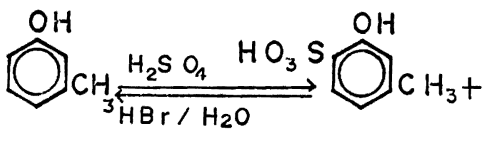

[3]

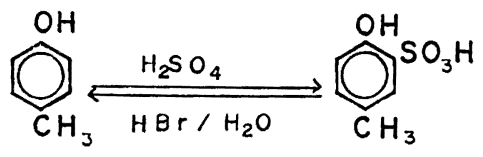

[5]
Fig. 1 Cresolsulfonic acids 
Table 1 Properties of cresolsulfonic acids

\begin{tabular}{|c|c|c|c|c|c|c|}
\hline \multirow{2}{*}{$\begin{array}{l}\text { Sulfonic } \\
\text { acid }\end{array}$} & \multirow{2}{*}{$\begin{array}{c}\text { IR }\left(\mathrm{cm}^{-1}\right) \text { of } \mathrm{K} \text {-salt } \\
(\mathrm{KBr})\end{array}$} & \multirow{2}{*}{$\begin{array}{l}\text { NMR }(\mathrm{ppm})^{a)} \text { of } \mathrm{K} \text {-salt } \\
\left(\text { in } \mathrm{D}_{2} \mathrm{O}\right)\end{array}$} & \multirow{2}{*}{\multicolumn{2}{|c|}{$\begin{array}{c}\mathrm{mp} \text { of } \\
\text { derivatives } \\
\left({ }^{\circ} \mathrm{C}\right)\end{array}$}} & \multicolumn{2}{|c|}{$\begin{array}{c}\text { Elemental analysis } \\
\text { of } \mathrm{SPN} \text {-salts } \\
\mathrm{C}_{15} \mathrm{H}_{17} \mathrm{~S}_{2} \mathrm{O}_{6} \mathrm{~N}_{3}\end{array}$} \\
\hline & & & & & Found $(\%)$ & Calcd. (\%) \\
\hline$[1]$ & $\begin{array}{l}\nu_{(\mathrm{OH})} 3450, \nu_{\mathrm{s}}(\mathrm{SO}) 1030 \\
\delta_{(1,2,3-\mathrm{Ar})} 730\end{array}$ & $\begin{array}{l}2.10 \sim 3.00(\mathrm{~m}, \mathrm{H}, \mathrm{Ar} \mathbf{H}) \\
-2.45\left(\mathrm{~s}, 3 \mathrm{H}, \mathrm{CH}_{3}\right)\end{array}$ & $\begin{array}{l}\text { S-salt } \\
\text { SPN-salt } \\
\text { A-salt }\end{array}$ & $\begin{array}{r}107.0 \\
155.2 \\
177.8\end{array}$ & $\begin{array}{rr}\mathrm{C} & 44.95 \\
\mathrm{H} & 4.08 \\
\mathrm{~S} & 15.84\end{array}$ & $\begin{array}{r}45.10 \\
4.26 \\
16.05\end{array}$ \\
\hline$[2]$ & $\begin{array}{l}\nu(\mathrm{OH}) 3520, \nu_{\mathrm{B}}(\mathrm{SO}) 1032 \\
\delta(1,2,4-\mathrm{Ar}) \\
827\end{array}$ & $\begin{array}{l}2.93(\mathrm{~s}, 1 \mathrm{H}, \mathrm{Ar} \mathbf{H}) \\
2.83(\mathrm{~d}, 1 \mathrm{H}, J=10, \operatorname{Ar} \mathbf{H}) \\
2.23(\mathrm{~d}, 1 \mathrm{H}, J=10, \operatorname{Ar} \mathbf{H}) \\
-2.48\left(\mathrm{~s}, 3 \mathrm{H},-\mathrm{CH}_{3}\right)\end{array}$ & $\begin{array}{l}\text { S-salt } \\
\text { SPN-salt } \\
\text { A-salt }\end{array}$ & $\begin{array}{r}174.8 \\
160.2 \\
189.8\end{array}$ & $\begin{array}{lr}\mathrm{C} & 44.89 \\
\mathrm{H} & 4.13 \\
\mathrm{~S} & 15.85\end{array}$ & $\begin{array}{r}45.10 \\
4.26 \\
16.05\end{array}$ \\
\hline [3] & $\begin{array}{l}\nu_{(\mathrm{OH})} 3150, \nu_{\mathrm{s}}(\mathrm{SO}) 1018 \\
\delta(1,2,4-\mathrm{ArH}) \\
800\end{array}$ & $\begin{array}{l}3.00(\mathrm{~d}, 1 \mathrm{H}, J=10, \operatorname{Ar} \mathbf{H}) \\
2.13(\mathrm{~s}, 1 \mathrm{H}, \operatorname{Ar} \mathbf{H}) \\
2.07(\mathrm{~d}, 1 \mathrm{H}, J=10, \operatorname{Ar} \mathbf{H}) \\
-2.10\left(\mathrm{~s}, 3 \mathrm{H},-\mathrm{CH}_{3}\right)\end{array}$ & $\begin{array}{l}\text { S-salt } \\
\text { SPN-salt } \\
\text { A-salt }\end{array}$ & $\begin{array}{l}146.7 \\
206.5 \\
174.2\end{array}$ & $\begin{array}{rr}\text { C } & 44.82 \\
H & 4.02 \\
\text { S } & 15.91\end{array}$ & $\begin{array}{r}45.10 \\
4.26 \\
16.05\end{array}$ \\
\hline$[4]$ & $\begin{array}{l}\nu_{(\mathrm{OH})} 3500, \nu_{\mathrm{B}(\mathrm{SO})} 1020 \\
\delta_{(1,2,4-\mathrm{Ar})} 825\end{array}$ & $\begin{array}{l}2.90(\mathrm{~d}, 1 \mathrm{H}, J=10, \operatorname{Ar} \mathbf{H}) \\
2.10(\mathrm{~s}, 1 \mathrm{H}, \operatorname{Ar} \mathbf{H}) \\
2.10(\mathrm{~d}, 1 \mathrm{H}, J=10, \operatorname{Ar} \mathbf{H}) \\
-2.40\left(\mathrm{~s}, 3 \mathrm{H},-\mathrm{CH}_{3}\right)\end{array}$ & $\begin{array}{l}\text { S-salt } \\
\text { SPN-salt } \\
\text { A-salt }\end{array}$ & $\begin{array}{r}150.5 \\
199.2 \\
156.3\end{array}$ & $\begin{array}{rr}\mathrm{C} & 44.80 \\
\mathrm{H} & 3.95 \\
\mathrm{~S} & 15.83\end{array}$ & $\begin{array}{r}45.10 \\
4.26 \\
16.05\end{array}$ \\
\hline$[5]$ & $\begin{array}{l}\nu_{(\mathrm{OH})} 3400, \nu_{\mathrm{S}}(\mathrm{SO}) 1022 \\
\delta(1,2,4-\mathrm{Ar}) \cdot 812\end{array}$ & $\begin{array}{l}2.87(\mathrm{~s}, 1 \mathrm{H}, \mathrm{Ar} \mathbf{H}) \\
2.69(\mathrm{~d}, 1 \mathrm{H}, J=10, \operatorname{Ar} \mathbf{H}) \\
2.22(\mathrm{~d}, 1 \mathrm{H}, J=10, \operatorname{Ar} \mathbf{H}) \\
-2.55\left(\mathrm{~s}, 3 \mathrm{H},-\mathrm{CH}_{3}\right)\end{array}$ & $\begin{array}{l}\text { S-salt } \\
\text { SPN-salt } \\
\text { A-salt }\end{array}$ & $\begin{array}{l}132.3 \\
164.8 \\
196.5\end{array}$ & $\begin{array}{lr}\mathrm{C} & 45.00 \\
\mathrm{H} & 4.02 \\
\mathrm{~S} & 15.78\end{array}$ & $\begin{array}{r}45.10 \\
4.26 \\
16.05\end{array}$ \\
\hline
\end{tabular}

\section{2 実験}

\section{1 クレゾール類の製造}

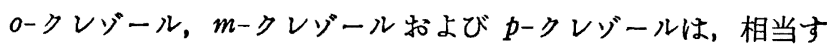
るトルイジンからジアゾ化一加水分解法でつくった。クレゾキシ 酢酸の融点は，それぞれ $153 ， 102 ， 136^{\circ} \mathrm{C}$ (文献值) ${ }^{4}$ 152, 102, $\left.136^{\circ} \mathrm{C}\right)$ 。

\subsection{2 -メチルフェノール-6-スルホン酸 [1]}

文献5)に準じて，ーークレゾールを低温でスルホン化後，バリウ ム塩として結晶を得（[2]は沪液にくる），水から再結晶を行な った。

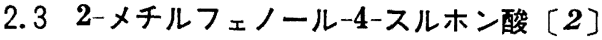

○ークレゾールを高温でスルホン化したのち，カリウム塩として 分離しだ。

\subsection{3 -メチルフェノール-6-スルホン酸 [3]}

文献7)にしたがってパリウム塩としてわけた。

\subsection{3 -メチルフェノール-4-スルホン酸 [4]}

〔3]を分離した沪夜からカリウム塩として採取した。

2.64 -メチルフェノール-2-スルホン酸 $[5]^{8)}$

\section{7 スルホン酸類の精製}

スルホン酸アルカリ塩を水に溶かし, 塩酸酸性で当量よりやや 過㮃のアニリンを加兄, 加熱溶解して均一溶液とした。冷後析出 するスルホン酸のアニリニウム塩")(以下 A-塩と略記する) の結 晶を融点が変わらなくなるまで反復して再結晶を行なった。この

4) C. F. Koelsch, J. Amer. Chem. Soc., 53, 304(1931).

5) A.d. Claus, U.A. Jackson, J. Prakt. Chem., [2], 38, 388(1888).

6) E. Hantke, Ber., 20, 3210(1887).

7) R. D. Haworth, A. Lapworth, J.Chem. Soc., 1924, 1299.

8) R. Anschütz, Ann., 415, 74(1918).

9) L. F. Fiesser, J. Amer. Chem. Soc., 51, 2463(1929).
塩を炭酸カリウム溶夜で処理し, 遊離するアニリンをベンゼン抽 出あるいは水蒸気蒸留で除去し, 沪液を濃縮して得られる結晶を 熱メタノール, 水の順で再結晶を行なってスルホン酸カリウムと した。これらのカリウム塩の IR $\left(\mathrm{cm}^{-1}\right)(\mathrm{KBr}), \mathrm{NMR}(\mathrm{ppm})\left(\mathrm{D}_{2} \mathrm{O}\right.$ 溶夜, $\mathrm{H}_{2} \mathrm{O}$ 基準) ならびに $S$-ペンジルチウロニウム塩 $(S \text {-塩 })^{10)}$,

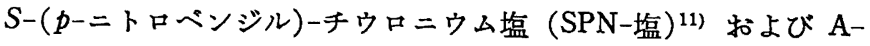
塩の融点を表 1 にまとめて記述した。

\section{8 反応温度ならびに硫酸濃度を変えてのクレソールのスル} ホン化反応

m-クレゾール拉よび p-クレジールをそれぞれ $10 \mathrm{~g}$ とり，反 応温度を $30 \sim 100^{\circ} \mathrm{C}$ の間で変化させ，55～90\% 硫酸 $150 \mathrm{~g}$ を用 いて， 2 時間スルホン化反応を行なった。反応終了後 $1 l$ の水中 に注意して加え, 炭酸バリウムで中和し, 沪過後残留物の硫酸ハ リウムに付着しているスルホン酸を水でよく洗浄し，汇夜を合わ せ (約 $1.5 l$ となる)，ついで $300 \mathrm{~m} l$ にまで濃縮した。これに 炭酸バリウムの白濁が，さらにみられなくなるまで注意して炭酸 カリウムのうすい溶液を加え，沪過後汇夜を湯浴上で乾固した。 これを熱メタノールに溶かし，ごくわずかに存在する不溶物を除 き,メタノールを留去してスルホン酸カリウムを製した。

\section{9 クレソールスルホン酸類の臭化水素酸による加水分解}

硬質試験管にそれぞれ [1]，[2]，[3]，[4]拈よび〔5]の カリウム塩 $226 \mathrm{mg}(0.001 \mathrm{~mol})$ をとり, これに $47 \%$ 臭化水素 酸 $5 \mathrm{ml}$ を加えて封管として，ふりまぜ式オイル恒温槽中に浸た し, 一定温度に一定時間たもった。反応後水で注意して希釈して $200 \mathrm{ml}$ としたものに, $1 \%$ 塩化バリウム溶液 $100 \mathrm{ml}$ を加え, 生 じた硫酸バリウムを沪過し、ルシボで焼いて科量を行なった。

10) J. J. Donleavy, J. Amer. Chem. Soc., 58, 1004(1936); E. Chamber, G. W. Watt, J. Org. Chem., 6, 376(1941); 村 本度博, 科学々工業, 30, 23(1956).

11) T. Momose, Y. Ohkura, Chem. Parm. Bull. Jap., 2, 54 


\section{3 結果および考察}

$3.1 \boldsymbol{m}$-クレゾールおよび $\boldsymbol{p}$-クレゾールのスルホン化結果お よび考察

m-クレゾール抽よび p-クレV゙ールのスルホン化について, Campbel12) は温度の影響をみているが，もっと詳細に知るために 硫酸濃度は 55９0\%，反応温度は $30 \sim 100^{\circ} \mathrm{C}$ の範盲で変化させ て，2 時間スルホン化反応を行ない，種々の条件下に拉ける両者 の反応性について検討を加えた。一般にクレゾール類は硫酸でス ルホン化を受けやすい。本実験のモノスルホン酸カリウム塩の理 論収量は $20.9 \mathrm{~g}$ であるが, 硫酸を過剩に用いる場合, 温度が高 くなるかまたは硫酸濃度が大となると, 得られるスルホン酸カリ ウムの収量が $20.9 \mathrm{~g}$ を越えて多くなり, ジスルホン酸が混合し てくる。いろいろの場合の実験で，スルホン化して得られたカリ ウム塩を反応温度に対してプロットした結果を, $m$ ークレジールス ルホン酸については図 2 に, p-クレジールスルホン酸については 図 3 に示す。

図 2 からスルホン酸カリウムの収量が，ほぼモノスルホン酸カ リウムの理論值に近いスルホン化の条件は，80\% 硫酸のとき反 応温度は $30^{\circ} \mathrm{C}$ であり, $77 \%$ 硫酸で $50^{\circ} \mathrm{C}, 75 \%$ 硫酸で $60^{\circ} \mathrm{C}$, $73 \%$ 硫酸で $70^{\circ} \mathrm{C}, 70 \%$ 硫酸で $80^{\circ} \mathrm{C}, 67 \%$ 硫酸で $90^{\circ} \mathrm{C}$ 就よび $65 \%$ 硫酸で $100^{\circ} \mathrm{C}$ となり, $65 \%$ 以下の硫酸では, $100^{\circ} \mathrm{C}$ で $m$ クレゾール全部をモノスルホン化することは困難となる。90\% 硫酸を用いて $100^{\circ} \mathrm{C}$ で反応を行なったものの収量は，モノスル ホン化物の理論量よりもはるかに多く生成して括り，硫黄の分析 值は $19.8 \%$ で，ジスルホン酸とトリスルホン酸の中間の値が得 られた。

図 3 から pークレゾールの反応をみると，85\% 硫酸で $40^{\circ} \mathrm{C}$, $77 \%$ 硫酸で $70^{\circ} \mathrm{C}, 75 \%$ 硫酸で $80^{\circ} \mathrm{C}, 73 \%$ 硫酸で $90^{\circ} \mathrm{C}, 70 \%$ 硫酸で $100^{\circ} \mathrm{C}$ となった。

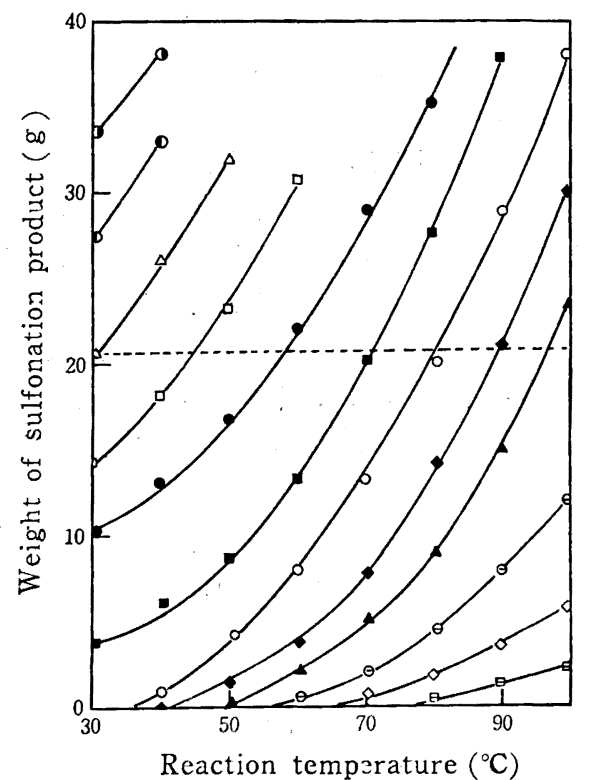

Fig. 2 Sulfonation of $m$-cresol

$\mathrm{H}_{2} \mathrm{SO}_{4}(\%)$
(1):90,
$: 85, \triangle: 80, \square: 77$ $: 75$
$0: 70$ $67, \Delta: 65$
$\ominus: 60$
$\diamond: 58$
$: 73$,

- - : : Theoretical yield

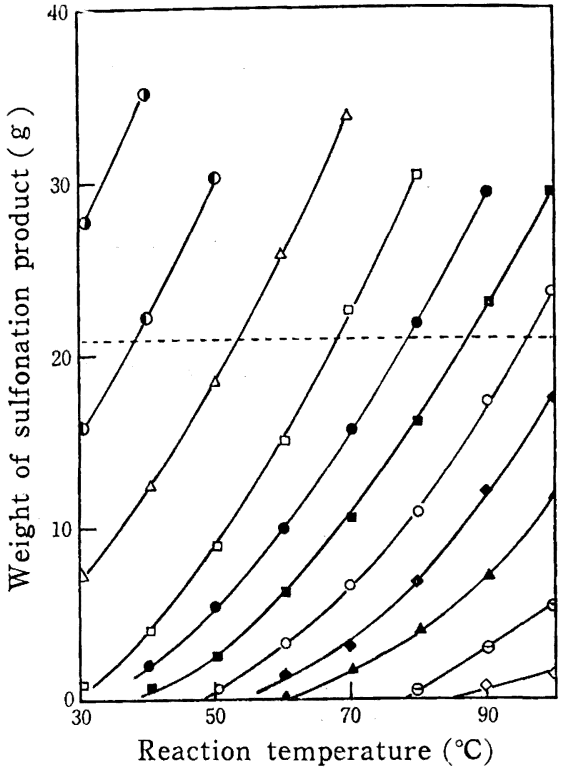

Fig. 3 Sulfonation of $p$-cresol

$\mathrm{H}_{2} \mathrm{SO}_{4}(\%)$

(1:90, $1: 85, \triangle: 80, \square: 77, \bigcirc: 75, \square: 73$,

$\bigcirc: 70, \diamond: 67, \Delta: 65, \ominus: 60, \diamond: 58$

- - : Theoretical yield

ほとんどの m-クレゾールがモノスルホン化を受け， $p$-クレジ ールのスルホン化があまり起こらない条件は，70\% 硫酸を用い た場合 $80^{\circ} \mathrm{C}, 77 \%$ 硫酸で $50^{\circ} \mathrm{C}, 80 \%$ 硫酸で $30^{\circ} \mathrm{C}$ であった。 一般に低温で低濃度の硫酸を用いるとき， $m$-クレゾールと $p$-ク

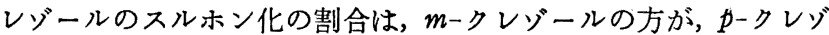
ールより 3〜5 倍の収量であった。しかし反応温度が上昇するほ ぞ，および硫酸濃度が増加するほど両者の差は縮少される傾向を 認めた。

\section{2 クレゾールスルホン酸類の脱スルホン化速度定数}

クレゾールスルホン酸類の脱スルホン化は, 希硫酸を用いるの が実際的に近い条件であるが，加水分解によって生成する硫酸の 測定が不可能であり，また硫酸濃度条件によっては，再スルホン 化が起こって複雑化すると考えられたので，比較的測定しやすい 47\% 臭化水素酸を使用して，反応の進行状態をみることにした。

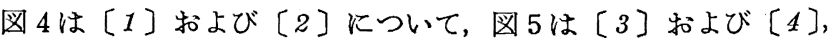

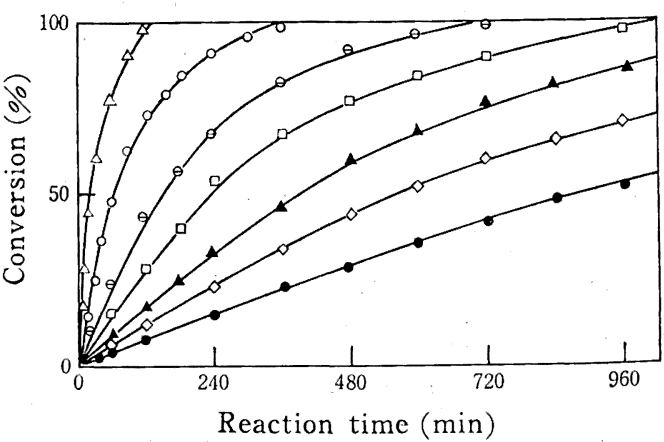

Fig. 4 Desulfonation of $o$-cresolsulfonic acids

[1] Temp. $\left({ }^{\circ} \mathrm{C}\right)$ $\triangle: 110, \bigcirc: 100, \square: 90, \diamond: 80$

[2] Temp. $\left({ }^{\circ} \mathrm{C}\right)$ $\ominus: 120, \mathbf{\Delta}: 110, \boldsymbol{O}: 100$ 


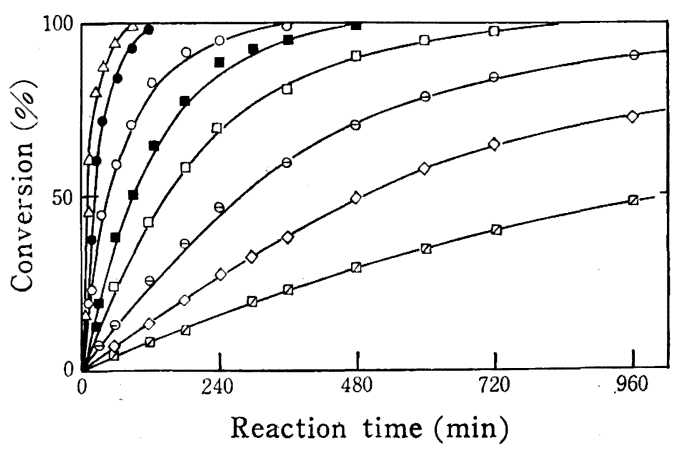

Fig. 5 Desulfonation of $m$-cresolsulfonic acids
[3] Temp. $\left({ }^{\circ} \mathrm{C}\right)$
$\triangle: 110, \bigcirc: 100, \square: 90, \diamond: 80$
[4] Temp. $\left({ }^{\circ} \mathrm{C}\right)$
$: 100, \square: 90, \ominus: 80, \square: 70$

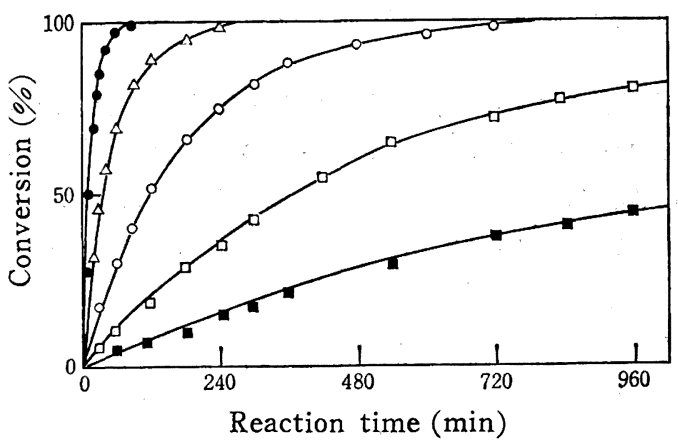

Fig. 6 Desulfonation of $p$-cresolsulfonic acid [5] Temp. $\left({ }^{\circ} \mathrm{C}\right)$

: $120, \triangle: 110, \bigcirc: 100, \square: 90, \square: 80$

図6は[5]の脱スルホン化の状況を時間(分)に対してプロット したものである。反応温度の高いほどよく脱スルホン化は進行し， 長時間では全部加水分解された。加水分解速度はつぎの順であっ た。

$$
[4]>[3]>[1]>[5]>[2]
$$

そこで反応の変化量の対数値, すなわち $\log (a-x)$ を時間(分) に対してプロットするとき，いずれの場合も直線を与えた。図 7 は $100^{\circ} \mathrm{C}$ に拈ける $\log (a-x)$ の值と時間との関係を代表的に示 したものである。

以上の結果から, クレゾールスルホン酸類の脱スルホン化反応 は， $k_{t}=\ln a /(a-x)$ の式にしたがって，擬一次反応として進む ことが判明した。そこで $\log k$ を絶体温度の逆数 $(1 / T)$ に対し

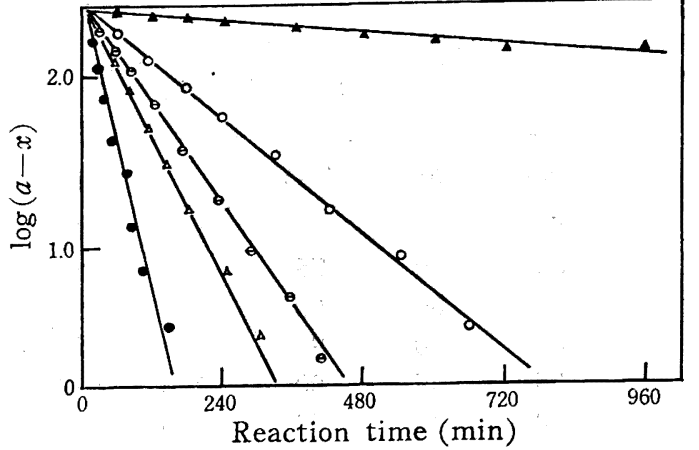

Fig. 7 Plots of $\log (a-x)$ againt reaction time

$\ominus:[1], \Delta:[2], \triangle:[3], \bigcirc:[4], \bigcirc:[5]$

てプロットすると，いずれも直線となったので，その傾斜から活 性化エネルギーを求めた。表 2 に脱スルホン化速度定数および活 性化エネルギーの値をまとめて記す。

$3.3 m$-クレソールの選択的スルホン化ならびに $m$-クレソー ルの分離

粗クレゾール中の 0 クレゾールおよび少量のキシレノールな どは, 沸点差を利用して蒸留により ${ }^{12)}$ 分留できるので除外して, mーおよび $p$ ークレゾール混合物について実験を行なった。定量法 としては発煙硝酸によるトリニトロ化法 ${ }^{13)}$ を採用し，尿素付加物 による方法 ${ }^{14)}$ 和よびガスクロマトグラフ法をる比較したが，いず れす近似した值であった。

Rasschig ${ }^{2)}$ は混合クレゾール (メタ体 60\%，パラ体 40\%) を スルホン化するのに，4 倍重量の硫酸，または 3 倍重量の $20 \%$ 発煙硫酸を用いて $100^{\circ} \mathrm{C}$ で反応を行なっており, 冷却後結晶と して析出する $p$ クレン゙ールスルホン酸をわかち，その沪液に過 熱水蒸気を通じて蒸留し，120 $130^{\circ} \mathrm{C}$ で $m$-クレジールを, 140 〜160 C で $p$-クレゾールを得ているが，追試の結果この方法で は，ジスルホン酸がかなり生成して括り，pークレゾールの分離法 としてはよいが，mークレゾールの純度および収率は低かった。 Brückner ${ }^{2)}$ は加水分解温度を $m$-クレデールスルホン酸で 116

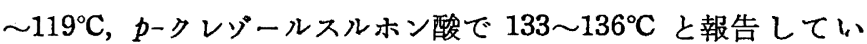
るが，この温度では低すぎて長時間を要し，完全に分解され難た い。スルホン酸アンモニウム塩とすると, メタ体の方がパラ体よ り溶解度が小さい。このことから Campbel12) は, アンモニウム 塩を結晶として分離したのち，分解して高純度の $m$ ークレジール を得ているが, 収量が低く操作が複雑となる。

スルホン化はクレゾール混合物中の $m$ ークレゾールだけが，選 択的に反応を受けるように低濃度の硫酸を用いて，低温で行なう

Table 2 Desulfonation rate constants of cresolsulfonic acids with $47 \%$ hydrobromic acid

\begin{tabular}{cccccccc}
\multirow{2}{*}{$\begin{array}{c}\text { Cresolsulfonic } \\
\text { acids }\end{array}$} & \multicolumn{9}{c}{ Rate constant $\left(\mathrm{min}^{-1}\right) \times 10^{-3}$} & at & $\begin{array}{c}\text { Activation } \\
\text { energy } \\
\text { (kcal/mol })\end{array}$ \\
\cline { 2 - 8 } & $120^{\circ} \mathrm{C}$ & $110^{\circ} \mathrm{C}$ & $100^{\circ} \mathrm{C}$ & $90^{\circ} \mathrm{C}$ & $80^{\circ} \mathrm{C}$ & $70^{\circ} \mathrm{C}$ & 31.7 \\
{$[1]$} & & 32.4 & 10.1 & 3.27 & 0.998 & & 33.9 \\
{$[2]$} & 6.56 & 1.99 & 0.635 & & & & 30.8 \\
{$[3]$} & & 45.1 & 15.1 & 4.86 & 1.54 & & 30.0 \\
{$[4]$} & & & 26.7 & 7.95 & 2.84 & 0.735 & 32.5 \\
{$[5]$} & 62.7 & 19.5 & 5.99 & 1.83 & 0.567 & &
\end{tabular}

12）正井省三，工化，38，509(1935).

14）尾野佳夫, “アロマチックス”, 22, 600(1970).

13）和田梓之助, 川合逸郎, 工化，37，1534(1934). 
Table 3 Separation of $m$-cresol

\begin{tabular}{|c|c|c|c|c|c|c|c|c|c|c|}
\hline \multirow{2}{*}{\multicolumn{2}{|c|}{$\begin{array}{l}\text { Cresols } \\
\quad(\mathrm{g})\end{array}$}} & \multirow{2}{*}{\multicolumn{2}{|c|}{ Sulfuric acid }} & \multirow{2}{*}{\multicolumn{2}{|c|}{$\begin{array}{l}\text { Reaction temp. } \\
\left({ }^{\circ} \mathrm{C}\right)\end{array}$}} & \multicolumn{2}{|c|}{ Unreacted cresol } & \multirow{3}{*}{$\begin{array}{c}\text { Hydrolysis } \\
\text { temp. } \\
\left({ }^{\circ} \mathrm{C}\right)\end{array}$} & \multicolumn{2}{|c|}{$m$-Cresol } \\
\hline & & & & & & \multirow{2}{*}{$\begin{array}{l}\text { Yield } \\
(\mathrm{g})\end{array}$} & \multirow{2}{*}{$\begin{array}{c}\text { Purity of } \\
p \text {-cresol } \\
(\%)\end{array}$} & & \multirow{2}{*}{$\begin{array}{l}\text { Yield } \\
(\mathrm{g})\end{array}$} & \multirow{2}{*}{$\begin{array}{c}\text { Purity of } \\
m \text {-cresol } \\
(\%)\end{array}$} \\
\hline$m-$ & $p-$ & $(\%)$ & $(g)$ & $(2 \mathrm{hr})$ & $(3 \mathrm{hr})$ & & & & & \\
\hline 50 & 50 & 75 & 500 & 20 & $\sim 40$ & 62 & 76 & $120 \sim 135$ & 25 & 98.2 \\
\hline 50 & 50 & 75 & 250 & 20 & $\sim 100$ & 45 & 82 & $120 \sim 135$ & 40 & 97.0 \\
\hline 50 & 50 & 90 & 99 & 20 & $\sim 100$ & 41 & 83 & $120 \sim 135$ & 41 & 97.0 \\
\hline 50 & 50 & 80 & 165 & 20 & $\sim 100$ & 42 & 82 & $120 \sim 135$ & 40 & 97.2 \\
\hline 55 & 45 & 90 & 106 & 20 & $\sim 100$ & 39 & 82 & $120 \sim 135$ & 46 & 97.4 \\
\hline 60 & 40 & 90 & 113 & 20 & $\sim 100$ & 34 & 83 & $120 \sim 135$ & 52 & 97.2 \\
\hline 60 & 40 & 80 & 187 & 20 & $\sim 100$ & 36 & 81 & $120 \sim 135$ & 51 & 97.5 \\
\hline 65 & 35 & 90 & 119 & 20 & $\sim 100$ & 28 & 83 & $120 \sim 135$ & 58 & 97.7 \\
\hline 70 & 30 & 90 & 126 & 20 & $\sim 100$ & 23 & 82 & $120 \sim 135$ & 63 & 97.7 \\
\hline 70 & 30 & 80 & 209 & 20 & $\sim 100$ & 25 & 80 & $120 \sim 135$ & 62 & 98.0 \\
\hline 75 & 25 & 90 & 133 & 20 & $\sim 100$ & 21 & 82 & $120 \sim 135$ & 64 & 98.0 \\
\hline 80 & 20 & 90 & 139 & 20 & $\sim 100$ & 15 & 83 & $120 \sim 135$ & 73 & 98.2 \\
\hline 80 & 20 & 80 & 230 & 20 & $\sim 100$ & 18 & 81 & $120 \sim 135$ & 71 & 98.8 \\
\hline 90 & 10 & 90 & 154 & 20 & $\sim 100$ & 8 & 78 & $120 \sim 135$ & 83 & 99.0 \\
\hline
\end{tabular}

のが望ましいが，しかしこのとき含有 $p$ ークレゾールの $1 / 5$ がス ルホン化されるのは防止できない。加水分解温度についていろい ろ実駺を行なった結果， $m$ ークレゾールの場合は $120 \sim 135^{\circ} \mathrm{C}$ が最 適と思われた。

実験として $1: 1$ の $m$-拈よび $p$-混合クレv゙ール $100 \mathrm{~g}$ を $75 \%$ 硫酸 $500 \mathrm{~g}$ 中に加え, $20 \sim 40^{\circ} \mathrm{C}$ でスルホン化を行ない, 未 反応クレゾールをベンゼン抽出して除き，スルホン化物に 120〜 $135^{\circ} \mathrm{C}$ で過熱水蒸気を通じて加水分解すると, 得られる $m$-クレ ゾールの純度はよいが，未反応が多く収率が悪かった。つぎに同 じ硫酸 $250 \mathrm{~g}$ ではじめ $20^{\circ} \mathrm{C} に 2$ 時間, のち徐々に注意して温度 を上げ, $100^{\circ} \mathrm{C} て ゙ 3$ 時間反応を行なったものについて, 同しよう に加水分解すると収量も上昇してきた。しかし技術的には硫酸量 の少ない方が便利であるので，90\% および $80 \%$ 硫酸を用いて， 低温で 2 時間反応させた。このとき硫酸はかなり $m$ ークレゾール の反応に消費されて希釈される。収量を上げるためにおだやかに 温度を上げて, $100^{\circ} \mathrm{C}$ に 3 時間たるち, $m$ ークレゾールの全部と $p$ クレゾールの $1 / 5$ が反応し，乙かも廃酸が $63 \sim 65 \%$ になるよう に, 硫酸量を計算して使用し（この硫酸濃度中では $p$-クレン゙ー
ルの反応性は少ない)，同しようにして加水分解を行なった。以 下混合クレゾール中の $m$-クレゾールの含有量 $50 \%$ のもの, 55, $60 ， 65 ， 70 ， 75 ， 80$ 扎よび $90 \%$ の場合も同じように実験した結 果を表 3 に示す。いずれの場合す得られた は, 97〜99\% で, 含有 m-クレジールの 80〜90\% が分離され, mークレン゙ールの含量の多い混合物の場合ほど収量のよいことが 認められる。

\section{$3.4 \boldsymbol{p}$-クレゾールの精製}

純度 80〜90\% の粗 $p$ ークレゾールを 75\% 硫酸とよくふりま ぜて，できるだけ反応しやすい 変えて除き, 未反応物に濃硫酸を 3 倍量（重量比）加えて $10^{\circ} \mathrm{C}$ で完全にスルホン化した。ついで全体の 2 倍量の水を追加し, $120 \sim 135^{\circ} \mathrm{C}$ に 2 時間たもって, 少量含まれている $m$-クレゾール スルホン酸を分解除去したのち，140 $160^{\circ} \mathrm{C}$ で過熱水蒸気を通 じて分解留出する油分を集めると純度 $97 \%$ 以上の $p$-クレゾー ルを得ることができた。

(1972 年 4 月, 日本化学会第 26 春季年会(一部)講演)

\title{
Desulfonation Rates of Cresolsulfonic Acids and Separation of $\boldsymbol{m}$-Cresol
}

\author{
Yoshihiro Muramoto and Hideyuki Asakura \\ Department of Industrial Chemistry, Faculty of Engineering, \\ Kinki University; Hiro-machi, Kure-shi 737-01 Japan
}

The rates of desulfonation of cresolsulfonic acids were determined and the separation method of pure $m$-cresol from the mixture of $m$ - and $p$-cresol was improved by means of the sulfonation-desulfonation process.

For the rate determination, the desulfonations were carried out by heating 2-methylphenol6-[1] and -4-sulfonic acids [2], 3-methylphenol-6-[3] and -4-sulfonic acids [4], and 4methylphenol-2-sulfonic acid [5] with 47\% hydrobromic acid, and the reactions were found to obey pseudo-first-order kinetics.

The desulfonation rate constants of $[1] \sim[5]$ at $100^{\circ} \mathrm{C}$ were $10.1,0.635,15.1,26.7,5.99$ $\times 10^{-3} \mathrm{~min}^{-1}$ respectively.

$m$ - And $p$-cresols were sulfonated with dilute sulfuric acid at low temperature, and $m$-isomer was sulfonated 3 to 5 times as fast as $p$-isomer was.

The improved method for separation of almost pure $m$-cresol from the $m-\mid p$-mixture was 
as follows : the mixture was partially sulfonated with $90 \%$ sulfuric acid at $20^{\circ} \mathrm{C}$ for $2 \mathrm{hr}$, then the temperature was gradually raised to $100^{\circ} \mathrm{C}$ and kept at that temperature for $3 \mathrm{hr}$. The quantity of sulfuric acid was controlled to give $65 \%$ spent acid by sulfonating all of the $m$-cresol and one-fifth of the $p$-cresol in the mixture. The unsulfonated cresol was extraced with benzene and the sulfonated $m$-cresol was des with super-heated steam at $120 \sim 135^{\circ} \mathrm{C}$. The yield of $m$-cresol by this process was $80 \sim 90 \%$ and its purity was $97 \sim 99 \%$. 